\title{
Relative performance and efficiency of five Merino and Merino-type dam lines in a terminal crossbreeding system with Dormer or Suffolk sires
}

\author{
S.W.P. Cloete ${ }^{1,2 \#}$, J.J.E. Cloete ${ }^{1,3}$, M.J. Herselman ${ }^{4}$ and L.C. Hoffman ${ }^{1}$ \\ ${ }^{1}$ Department of Animal Sciences, University of Stellenbosch, Private Bag X1, Matieland 7602, South Africa \\ ${ }^{2}$ Elsenburg Agricultural Centre, Private Bag X1, Elsenburg 7607, South Africa \\ ${ }^{3}$ Elsenburg College of Agriculture, Private Bag X1, Elsenburg 7607, South Africa \\ ${ }^{4}$ Grootfontein Agricultural Development Institute, Private Bag X529, Middelburg 5900, South Africa
}

\begin{abstract}
The production performance of ewes was assessed in a terminal crossbreeding experiment involving five Merino and Merino-type dam lines and two terminal crossbreeding sire breeds. Dam lines were SA Mutton Merino (SAMM), SAMM rams crossed to Merino ewes (SAMM cross), Dohne Merino, as well as specialist Merino lines selected for clean fleece weight (FW+) and for an increased reproduction (Rep ${ }^{+}$). Dormer and Suffolk rams were used as sires. Dual-purpose ewes were heavier than Merinos on average and at the ultimate joining at 3.5 years. Average clean fleece weight for SAMM ewes was approximately half that of Merino ewes while clean fleece weights for Dohne and SAMM cross ewes were intermediate. Differences between progeny in slaughter age, marketing weight, dressing percentage and carcass weight could largely be attributed to the comparison of purebred Merino lines with dual-purpose lines. The slaughter age of lambs from the two Merino lines was between 14 and $21 \%$ higher than that of the dualpurpose lines. Lambs from purebred SA Mutton Merino (SAMM) dams also outperformed lambs from SAMM cross ewes for slaughter age, slaughter weight and carcass weight. Considerable variation was found between dam lines for reproduction parameters, but few significant differences were found. Lamb output, defined as total weight of lamb slaughtered per joining, averaged $42.7 \mathrm{~kg}$ for SAMM ewes, $44.2 \mathrm{~kg}$ for SAMM cross ewes, $39.3 \mathrm{~kg}$ for Dohne ewes, $32.9 \mathrm{~kg}$ for FW+ Merino ewes and $42.0 \mathrm{~kg}$ for Rep+ Merino ewes, but differences between lines only tended to be significant. Sire breed did not affect lamb performance or ewe productivity markedly. An economic simulation indicated large differences in gross income per small stock unit between dam lines, warranting further research on the efficiency of terminal Merino-type dam lines.
\end{abstract}

Keywords: Carcass yield, fibre diameter, gross income, lamb output, productivity, reproduction, wool yield ${ }^{\#}$ Corresponding author. E-mail: schalkc@elsenburg.com

\section{Introduction}

Fluctuations in the ratio between wool and meat prices have resulted in the emphasis on the two products changing markedly over the past decade. Commercial producers often seek other ways to exploit short-term benefits resulting from an increase in the price of meat than within flock selection, without compromising the wool-producing capacity of their ewe flocks (Erasmus, 1965). Crossbreeding of Merinotype ewes with mutton type rams in a terminal crossbreeding system may be considered to realize this goal (Kleeman et al., 1983). Such a system allows spreading of risk over the meat and wool commodities. It is also suitable for the exploitation of sexual dimorphism between dam and sire lines (Roux, 1992). This practice has often been implemented injudiciously in the past, resulting in wool contamination and the loss of genetic material needed for pure breeding (Erasmus, 1965).

This study evaluated a range of Merino-type bloodlines as dam lines in a terminal crossbreeding system. Lines were South African Mutton Merino (SAMM), SAMM rams crossed to Merino ewes, Dohne Merino, as well as specialist Merino lines selected for clean fleece weight or selected for an increased reproduction (Cloete et al., 2003). The SAMM and Dohne Merino breeds are important dual-purpose genotypes, producing apparel wool, free from undesirable fibres (Terblanche, 1979). These lines were found to outperform purebred Merino lines for live weight traits of the ewes and their crossbred progeny, but were inferior with regard to wool production (Cloete et al., 2003). SAMM rams are also used on Merino ewes to produce first-cross ewes for commercial lamb and wool production. The reproductive performance of such ewes compared to the parent breeds (SAMM and Merino) and the Dohne Merino has not been studied adequately (Erasmus et al., 1983; Cloete et al., 2003). All these genotypes may be considered as dam lines in a terminal crossbreeding system, without seriously compromising wool quality. When the economic 
implications of changes involving production systems are considered, it is necessary to include the impact of such changes upon the requirements of the breeding flock (White, 1984).

The lifetime (defined as three reproduction opportunities) performance, in terms of lamb and wool output, of the respective dam lines in a commercial, terminal crossbreeding system was studied, using Dormer and Suffolk rams as sires. The performance of these lines was entered into an economic simulation model, to get an indication of the relative economic yield expected from a terminal crossbreeding operation based on the respective dam lines.

\section{Material and Methods}

The experiment was carried out on the Langgewens experimental farm in the Swartland. The location and the husbandry of the animals used were described by Cloete et al. (2003). Merino-type ewes, of five distinct lines, represented the female breeding animals. These ewes were not selected as replacements in their flocks of origin, and were considered as ideal for slaughter lamb production in terminal crossbreeding. Evaluation took place over a four-year period, from 1999 to 2002. Between 39 and 41 ewes initially represented each line. The maternal lines were the following (for more details, see Cloete et al., 2003):

- SAMM ewes from the Elsenburg flock (Vosloo, 1967).

- A cross between SAMM rams and Merino ewes (SAMM cross line; Cloete \& Durand, 2000).

- Dohne Merino ewes from the Kromme Rhee Dohne Merino nucleus flock (Cloete et al., 1998b) for ewes born in 1997. Twenty two-tooth ewes bought in from a nearby property provided a 1998 ewe group.

- A Merino line selected for fleece weight, with a check on fibre diameter (FW+; Cloete et al., 1998a).

- A Merino line selected for the ability to rear multiples per joining (Rep+; Cloete \& Scholtz, 1998).

Dormer or Suffolk rams were used as terminal sires on the ewe flock. Dormer rams were obtained from the Elsenburg stud (Van Wyk et al., 2003) and Suffolk rams from industry (Cloete et al., 2003). Ewes were annually joined to $2-3$ rams of each breed in single sire groups to lamb during June-July. Live weights were recorded at joining. The final live weight that was recorded was considered as an indication of the mature live weight of the ewes. Lambs were weaned at an average ( \pm s.d.) age of $98 \pm 12$ days, and weaning weight was recorded, as described by Cloete et al. (2003). It was attempted to slaughter all lambs at a live weight of approximately $38-40 \mathrm{~kg}$. All remaining lambs were, however, slaughtered towards the end of February of each year. The seasonal period of nutritional short supply in the Swartland is expected to commence at this stage, and the lambs were slaughtered to ensure that they were not carried over into the next production season. Slaughter age and slaughter weight were known individually for 580 lambs. Cold carcass weight and dressing percentage of these lambs were measured after 24 hours in the cooler. Weight of lamb slaughtered per ewe per year was calculated from survival to slaughter age and lamb slaughter weight. Weight of carcass produced per ewe per year was determined correspondingly. Carcass classification was also acquired for 508 lamb carcasses, according to standard South African regulations (Bruwer et al., 1987). No lambs were downgraded for excessive fat depth (> A4). Lamb meat prices in the A0 - A3 range were fairly stable, except for somewhat lower prices for carcasses classified as A0. The proportion of carcasses of crossbred progeny with a better classification than A0 was thus compared between dam lines. Ewes were shorn during May-June, and clean fleece weight, staple strength and fibre diameter were determined individually. The data obtained in this way was used to obtain average annual production figures for each ewe. A total of 77 ewes was slaughtered at the end of the trial, and slaughter weight, dressing percentage and carcass weight were recorded. The ewes were maintained in a single flock, except during joining and lambing (Cloete et al., 2003). During mating, they were split up in single sire mating groups, and at lambing they were randomly allocated to smaller flocks to facilitate data recording.

The proportions of ewes surviving to the termination of the experiment and the classification of lamb and ewe carcasses were compared between dam lines by using $\mathrm{Chi}^{2}$ procedures (Siegel, 1956). Averaged lamb production and wool data were analysed according to a 5 (dam lines) X 2 (sire breeds) factorial analysis. Least squares procedures were used, to account for uneven subclasses (Harvey, 1990). Although sire breed was fitted for ewe weight and wool traits, it was not significant. These results are not presented, since no theoretical basis exists for differences in these traits between sire breeds.

Data obtained from the present study were combined with those obtained earlier by Cloete et al. (2003), and entered into the SM2000 economic simulation model (Herselman, 2002). Information on the details required by SM2000 for an economic simulation, is provided in the latter literature source. Since a terminal crossbreeding system involves the buying in of females, it was assumed that ewes were bought in at 
yearling age. It was assumed that they weighed $75 \%$ of their mature weight at this stage, and that they were bought in for slaughter value plus 20\%. Feeding costs are considered as a major cost item for commercial sheep production systems (Greeff et al., 1990; Schoeman et al., 1995). In the simulation of a specific crossbreeding system, live weight and growth rates were used as an indication of the energy requirements of ewes and lambs (ARC, 1980). Energy requirements were used for calculation of small stock units (SSU), where $1 \mathrm{SSU}$ is equivalent to 11.25 MJ ME/day. Expenses were not broken down further, but it was assumed that all dam lines were subjected to the same level of husbandry and health care, since they were maintained in a single flock. Results were thus expressed on a gross income per small stock unit (SSU) basis. Wool prices and meat prices were obtained from the industry. In order to provide an outcome with a measure of robustness, a range of wool prices was simulated against the current meat price, to result in a wool:meat price ratio range of $0.78-2.35$. Gross income was depicted against this ratio in a graph, to reflect the impact of varying wool prices upon the relative economic returns from the respective dam lines.

\section{Results and Discussion}

Ewe survival to the termination of the experiment was independent of dam line $\left(\mathrm{Chi}^{2}=3.39\right.$; $\mathrm{P}>$ 0.50), and proportions ranged between 0.90 and 0.78 for the dam lines (Table 1). Cumulative death rates for ewes up to their third production year were reported at 15\% for Merinos (Heydenrych, 1975) and 19\% for Dohne Merinos (Fourie, 1981). In a study involving pure-bred Merinos and six crossbred genotypes, survival to the fourth joining ranged from 89 - 98\% (Greeff et al., 1990). Expressed as an average per year, ewe deaths ranged between $3.3 \%$ and $7.3 \%$ in the present study. Annual ewe deaths ranged from $0-5.9 \%$ for Merino flocks and from $0.5-7.1 \%$ for Dohne Merino flocks in the Bredasdorp area of the southern Cape (Fourie \& Cloete, 1993). Lamb losses owing to ewe deaths amounted to $2-6 \%$ for Western Australian and New Zealand sheep flocks (Knight, 1990). The death rates incurred in the present study were well within these ranges.

Table 1 Numbers of breeding ewes of the respective dam lines available initially and at the termination of the experiment, as well as the proportion ewes surviving

\begin{tabular}{lccccc}
\hline Ewes available (n) & \multicolumn{4}{c}{ Dam line } \\
\cline { 2 - 6 } & SAMM & SAMM cross & Dohne & FW+ Merino & Rep+ Merino \\
\hline Initially & 41 & 40 & 39 & 39 & 39 \\
At termination of experiment & 37 & 31 & 33 & 33 & 35 \\
Proportion ewes survived & 0.90 & 0.78 & 0.85 & 0.85 & 0.90 \\
\hline
\end{tabular}

* Critical $\mathrm{Chi}^{2}$ for 4 degrees of freedom = 9.49; SAMM - South African Mutton Merino

Average ewe weight at joining of dual-purpose ewes was 13 - 14\% higher than in FW+ Merinos, and $24-25 \%$ higher than in Rep+ Merino ewes $(\mathrm{P}<0.01$; Table 2). Corresponding ranges of differences in ultimate live weight at the termination of the trial ranged from $15-19 \%$ and from $19-23 \%$ respectively (P $<0.01$ ). These differences accorded well with earlier estimates based on annual ewe joining weights (Cloete et al. 2003), as could be expected. Yearling live weight of SAMM and Dohne Merino progeny were correspondingly 33\% and 17\% higher than that of purebred Merinos (Cloete et al., 1999). Basson et al. (1969) also reported that mature Dohne Merino ewes were 24\% heavier than Merinos.

Table 2 Least squares means ( \pm s.e.) depicting the influence of dam line upon live weight (LW), clean fleece weight (CFW) and average wool traits (Staple strength - SS and Fibre diameter - FD) of breeding ewes available at third joining

\begin{tabular}{|c|c|c|c|c|c|c|}
\hline \multirow[t]{2}{*}{ Dam line } & \multicolumn{2}{|c|}{ LW (kg) } & \multicolumn{2}{|c|}{ CFW } & \multicolumn{2}{|c|}{ Average wool traits } \\
\hline & Average LW & Ultimate LW & $\begin{array}{l}\text { Average } \\
\text { CFW }\end{array}$ & $\begin{array}{c}\text { CFW as \% of } \\
\text { LW }\end{array}$ & SS (N/ktex) & $\mathrm{FD}(\mu \mathrm{m})$ \\
\hline SAMM & $63.5 \pm 0.8^{\mathrm{C}}$ & $67.4 \pm 1.1^{b}$ & $2.20 \pm 0.11^{\mathrm{a}}$ & $3.5 \pm 0.2^{\mathrm{a}}$ & $28.4 \pm 1.3^{\mathrm{a}}$ & $23.5 \pm 0.2^{c}$ \\
\hline SAMM Cross & $63.8 \pm 0.9^{c}$ & $65.5 \pm 1.2^{\mathrm{b}}$ & $3.24 \pm 0.11^{\mathrm{b}}$ & $5.1 \pm 0.2^{b}$ & $31.9 \pm 1.3^{\mathrm{b}}$ & $23.0 \pm 0.2^{\mathrm{b}}$ \\
\hline Dohne & $62.9 \pm 0.9^{c}$ & $65.1 \pm 1.2^{\mathrm{b}}$ & $3.53 \pm 0.11^{\mathrm{c}}$ & $5.7 \pm 0.2^{c}$ & $37.3 \pm 1.3^{c}$ & $22.0 \pm 0.2^{\mathrm{a}}$ \\
\hline FW+ Merino & $55.9 \pm 0.9^{b}$ & $56.7 \pm 1.1^{\mathrm{a}}$ & $4.81 \pm 0.11^{\mathrm{e}}$ & $8.6 \pm 0.2^{\mathrm{d}}$ & $40.7 \pm 1.3^{\mathrm{d}}$ & $22.9 \pm 0.2^{b}$ \\
\hline Rep + Merino & $50.9 \pm 0.9^{\mathrm{a}}$ & $54.7 \pm 1.2^{\mathrm{s}}$ & $4.19 \pm 0.11^{\mathrm{d}}$ & $8.3 \pm 0.2^{\mathrm{d}}$ & $35.9 \pm 1.3^{c}$ & $22.4 \pm 0.2^{\mathrm{a}}$ \\
\hline
\end{tabular}

The South African Journal of Animal Science is available online at http://www.sasas.co.za/Sajas.html 
Expressed relative to FW+ Merinos, average clean fleece weight of SAMM ewes amounted to $46 \%$ of that recorded in the former line (Table 2). Merinos were previously reported to produce approximately twice the quantity of clean wool than that produced by SAMM sheep (Greeff, 1990; Cloete et al., 1999; Cloete $e t$ al., 2003). Corresponding percentages were $67 \%$ for SAMM cross ewes, $73 \%$ for Dohnes and $87 \%$ for Rep + Merinos, all differences being significant $(\mathrm{P}<0.05)$. The wool yield of SAMM cross and Dohne Merino sheep was also reported to be roughly on the mid-parent value between the parent breeds (Basson et al., 1969; Greeff, 1990; Cloete et al., 1999; Cloete \& Durand, 2000). Clean fleece weight of SAMM Merino ewes amounted to roughly 3\% of average live weight, compared to about $8 \%$ in FW+ and Rep+ Merinos (P $<0.05$; Table 2). Dohne and SAMM cross ewes were intermediate.

Average staple strength increased $(\mathrm{P}<0.05)$ from SAMM ewes to $\mathrm{FW}+$ ewes. Expressed as a percentage of the average staple strength of $\mathrm{FW}+$ Merino ewes, performance levels amounted to $70 \%$ for SAMM ewes, $78 \%$ for SAMM cross ewes, $92 \%$ for Dohne Merino ewes and $88 \%$ for Rep+ Merino ewes. No previous results on the staple strength of the breeds under consideration were found, except for a previous study on the annual performance of the same resource flock (Cloete et al., 2003). Naturally, results from the latter study were in close correspondence with the present results. Between line variation in fibre diameter was lower. SAMM ewes produced 3\% coarser wool than FW+ Merinos. Previous studies suggested that the fibre diameter of SAMM sheep was 2 - 8\% higher than that of Merinos (Greeff, 1990; Brand et al., 1999; Cloete et al., 1999). Average fibre diameter of Dohne ewes was 4\% finer than that of FW+ Merinos. Previous studies on the relative performance of Dohne Merinos and Merinos pertaining to fibre diameter suggested small differences between the breeds (Greeff, 1990; Cloete et al., 1999). The generally higher fibre diameter of Merinos in the present study may be related to discrimination against ewes with an excessive fibre diameter in their flocks of origin (Cloete et al., 2003). Such ewes were, however, still regarded as suitable for terminal crossbreeding.

Approximately three-quarters of those lambs born were slaughtered in the terminal crossbreeding system (Table 3). The same percentage of lambs was slaughtered per lamb born in a crossbreeding trial reported by Malik et al. (2000). When dam line was considered, absolute means ranged from 0.71 for SAMM dams to 0.81 for Rep+ Merino dams $\left(\mathrm{Chi}^{2}=6.93\right.$; degrees of freedom $=4$; $\left.\mathrm{P}<0.25\right)$.

Table 3 Proportions of lambs slaughtered as well as least squares means ( \pm s.e.) depicting the influence of dam line and sire breed upon lamb slaughter and carcass traits

\begin{tabular}{lcccccc}
\hline Line & \multicolumn{2}{c}{ Lambs slaughtered } & $\begin{array}{c}\text { Slaughter age } \\
\text { (days) }\end{array}$ & $\begin{array}{c}\text { Slaughter } \\
\text { weight }(\mathrm{kg})\end{array}$ & Dressing \% & $\begin{array}{c}\text { Carcass } \\
\text { weight }(\mathrm{kg})\end{array}$ \\
\cline { 2 - 3 } Damber line & Proportion & & & & & \\
SAMM & 125 & 0.71 & $134 \pm 2^{\mathrm{a}}$ & $40.3 \pm 0.3^{\mathrm{c}}$ & $41.0 \pm 0.3^{\mathrm{c}}$ & $16.6 \pm 0.2^{\mathrm{d}}$ \\
SAMM Cross & 126 & 0.72 & $143 \pm 2^{\mathrm{b}}$ & $39.2 \pm 0.3^{\mathrm{b}}$ & $40.6 \pm 0.3^{\mathrm{c}}$ & $16.0 \pm 0.2^{\mathrm{c}}$ \\
Dohne & 109 & 0.80 & $142 \pm 3^{\mathrm{a}, \mathrm{b}}$ & $39.7 \pm 0.3^{\mathrm{b}, \mathrm{c}}$ & $40.0 \pm 0.3^{\mathrm{b}, \mathrm{c}}$ & $15.9 \pm 0.2^{\mathrm{c}}$ \\
FW+ Merino & 101 & 0.72 & $164 \pm 3^{\mathrm{c}}$ & $37.0 \pm 0.3^{\mathrm{a}}$ & $38.5 \pm 0.4^{\mathrm{a}}$ & $14.3 \pm 0.2^{\mathrm{a}}$ \\
Rep+ Merino & 120 & 0.81 & $165 \pm 2^{\mathrm{c}}$ & $37.8 \pm 0.3^{\mathrm{a}}$ & $39.3 \pm 0.3^{\mathrm{a}, \mathrm{b}}$ & $14.9 \pm 0.2^{\mathrm{b}}$ \\
Sire breed & & & & & \\
Dormer & 303 & 0.75 & $148 \pm 2$ & $38.9 \pm 0.2$ & $39.9 \pm 0.2$ & $15.6 \pm 0.1$ \\
Suffolk & 279 & 0.75 & $151 \pm 2$ & $38.7 \pm 0.2$ & $39.9 \pm 0.2$ & $15.5 \pm 0.1$ \\
\hline
\end{tabular}

* Critical $\mathrm{Chi}^{2}$ for 4 degrees of freedom = 9.49; SAMM - South African Mutton Merino

a,b,c,d,e Means in the same column with different superscripts differ $(\mathrm{P}<0.05)$

Slaughter age, slaughter weight, carcass weight and dressing percentage were affected $(\mathrm{P}<0.05)$ by dam line, but not by sire breed $(\mathrm{P}>0.10)$. Differences between dam lines could mostly be attributed to the comparison of purebred Merino lines with the dual-purpose lines (Table 3). Rathie \& Teasdale (1994) also found that purebred Merinos were outperformed by dual-purpose ewes. The lower dressing percentage of lambs from purebred Merino lines could be due to their generally thinner fat cover and more wool on the skins (Kirton et al., 1995). In relation to the dual-purpose lines, the slaughter age of lambs produced by dams from the two Merino dam lines was between 14 and 21\% higher $(\mathrm{P}<0.05)$. Although it was attempted to slaughter all lambs at a live weight of $38-40 \mathrm{~kg}$, this objective was not reached. In the quest to slaughter all progeny born before the expected short supply of nutrients in late summer, individuals were slaughtered when they started losing weight, and all remaining lambs were slaughtered by the middle of February each 
year. Especially the slower growing progeny of the two Merino lines had lower $(\mathrm{P}<0.05)$ slaughter weights than those of the dual-purpose lines. Carcass weights and dressing percentage followed the same pattern. Slaughter lambs produced by purebred SAMM dams also outperformed those reared by SAMM cross ewes for slaughter age, slaughter weight and carcass weight. These differences, however, failed to exceed $10 \%$ of the mean performance of purebred SAMM progeny. No corresponding results on the comparison of these lines were found in the literature.

Absolute means for number of lambs slaughtered per ewe joined ranged from 0.90 for $\mathrm{FW}+$ Merinos to 1.16 for SAMM cross ewes (Table 4; $\mathrm{P}=0.12$ ). The lines were previously also found not to differ for number of lambs weaned per ewe joined (Cloete et al., 2003). Average weight of lamb slaughtered per ewe joined ranged between approximately $33 \mathrm{~kg}$ for $\mathrm{FW}+$ Merino ewes to $\geq 42 \mathrm{~kg}$ for Rep+, SAMM and SAMM cross ewes, but the observed differences only approached significance $(P=0.07)$. Ewes in the SAMM cross line were previously found to outperform those in the FW+ line for weight of lamb weaned per ewe joined (Cloete et al., 2003). The superior growth performance of progeny of ewes in this line is also reflected in the lower age at slaughter in the present study. Average weight of carcass produced per ewe joined ranged from $12.7 \mathrm{~kg}$ per ewe for FW+ Merinos to nearly $18 \mathrm{~kg}$ of carcass produced per ewe joined for SAMM and SAMM cross ewes $(\mathrm{P}<0.05)$. No difference was found between sire breeds as far as number of lambs or weight of lamb slaughtered per ewe joined was concerned $(\mathrm{P}>0.50)$. No sire breed differences were correspondingly found in a previous study on the two sire breeds (Erasmus et al., 1983). When lamb output was expressed as percentage of average ewe live weight, means ranged between approximately $60 \%$ for $\mathrm{FW}+$ Merinos to $>80 \%$ for Rep + Merinos $(\mathrm{P}<0.05)$. Corresponding differences for weight of carcass produced per ewe joined ranged between $23 \%$ for $\mathrm{FW}+$ Merino ewes to $>32 \%$ for Rep + Merinos $(\mathrm{P}<0.05)$. The dual-purpose breeds were intermediate in both instances.

Table 4 Least squares means ( \pm s.e.) depicting the influence of dam line and sire breed upon average lamb output, expressed as number of lambs and weight of lamb or carcass produced

\begin{tabular}{|c|c|c|c|c|c|}
\hline \multirow[t]{2}{*}{ Line } & \multicolumn{3}{|c|}{ Slaughter lamb production per ewe joined } & \multicolumn{2}{|c|}{ Lamb produced as \% of LW } \\
\hline & Number & Weight (kg) & Carcass (kg) & Weight (\%) & Carcass (\%) \\
\hline \multicolumn{6}{|l|}{ Dam line } \\
\hline SAMM & $1.07 \pm 0.08$ & $42.7 \pm 2.9$ & $17.8 \pm 1.1^{\mathrm{b}}$ & $67.7 \pm 5.1^{\mathrm{a}, \mathrm{b}}$ & $28.2 \pm 2.0^{\mathrm{b}, \mathrm{c}}$ \\
\hline SAMM Cross & $1.16 \pm 0.08$ & $44.2 \pm 3.1$ & $17.6 \pm 1.2^{\mathrm{b}}$ & $70.2 \pm 5.4^{\mathrm{a}, \mathrm{b}}$ & $27.9 \pm 2.2^{\text {a,b.c }}$ \\
\hline Dohne & $0.99 \pm 0.08$ & $39.3 \pm 3.1$ & $15.7 \pm 12^{\mathrm{b}}$ & $63.3 \pm 5.4^{\mathrm{a}}$ & $25.4 \pm 2.2^{\mathrm{a}, \mathrm{b}}$ \\
\hline FW+ Merino & $0.90 \pm 0.08$ & $32.9 \pm 3.0$ & $12.7 \pm 1.2^{\mathrm{a}}$ & $59.7 \pm 5.2^{\mathrm{a}}$ & $23.0 \pm 2.1^{\mathrm{a}}$ \\
\hline Rep+ Merino & $1.12 \pm 0.08$ & $42.0 \pm 3.0$ & $16.4 \pm 1.2^{\mathrm{b}}$ & $83.4 \pm 5.3^{b}$ & $32.6 \pm 2.1^{c}$ \\
\hline \multicolumn{6}{|l|}{ Sire breed } \\
\hline Dormer & $1.05 \pm 0.05$ & $40.5 \pm 1.9$ & $16.3 \pm 0.8$ & $69.1 \pm 3.3$ & $27.7 \pm 1.3$ \\
\hline Suffolk & $1.04 \pm 0.05$ & $39.9 \pm 1.9$ & $15.8 \pm 0.8$ & $68.7 \pm 3.4$ & $27.1 \pm 1.3$ \\
\hline
\end{tabular}

Mean slaughter weights and dressing percentages of the dual-purpose dam lines were respectively 11 $16 \%$ and $10-14 \%$ higher than those of FW+ Merino ewes $(\mathrm{P}<0.05$; Table 5). Carcass weight was thus 22 - 33\% higher in dual-purpose ewes than in FW+ Merino ewes. No significant differences were found between FW+ and Rep+ Merino ewes. Results pertaining to the slaughter weight of the respective dam lines were consistent with the ultimate live weight means reported in Table 2.

Table 5 Least squares means ( \pm s.e.) depicting slaughter traits of ewes at the termination of the experiment

\begin{tabular}{lcccc}
\hline Dam line & Ewes slaughtered (n) & Live weight $(\mathrm{kg})$ & Dressing \% & Carcass weight $(\mathrm{kg})$ \\
\hline SAMM & 16 & $66.5 \pm 1.9^{\mathrm{b}}$ & $39.9 \pm 1.1^{\mathrm{b}}$ & $26.5 \pm 1.1^{\mathrm{b}}$ \\
SAMM Cross & 15 & $67.4 \pm 1.9^{\mathrm{b}}$ & $41.4 \pm 1.1^{\mathrm{b}}$ & $28.1 \pm 1.1^{\mathrm{b}}$ \\
Dohne & 14 & $64.6 \pm 1.9^{\mathrm{b}}$ & $40.1 \pm 1.1^{\mathrm{b}}$ & $25.9 \pm 1.2^{\mathrm{b}}$ \\
FW+ Merino & 15 & $58.1 \pm 1.9^{\mathrm{a}}$ & $36.4 \pm 1.1^{\mathrm{a}}$ & $21.2 \pm 1.1^{\mathrm{a}}$ \\
Rep+ Merino & 17 & $57.8 \pm 1.8^{\mathrm{a}}$ & $37.2 \pm 1.0^{\mathrm{a}}$ & $21.6 \pm 1.0^{\mathrm{a}}$ \\
\hline
\end{tabular}

${ }^{\mathrm{a}, \mathrm{b}}$ Means in the same column with different superscripts differ $(\mathrm{P}<0.05)$; SAMM - South African Mutton Merino 
Proportions of lamb carcasses being classified other than A0 did not differ between dam lines $\left(\mathrm{Chi}^{2}=\right.$ 1.84; degrees of freedom $=4 ; \mathrm{P}>0.50$; Table 6). No lambs were classified as A4 or higher since carcasses are expected to fetch lower prices as a results of consumer resistance against excessive fat. The average lamb price realised by progeny produced by the respective lines was thus very stable at between R 20.38 and R 20.47.

Table 6 Classification of lamb (grade A) and ewe (grade C) carcasses as well as meat and wool prices (expressed per kg) used in the economic analysis

\begin{tabular}{lccccccc}
\hline Dam Line & \multicolumn{2}{c}{ Lamb carcasses and classification code } & \multicolumn{2}{c}{ Ewe carcasses and classification code } & Wool price \\
\cline { 2 - 6 } & Number & $\geq$ A1* & Price $(\mathrm{R})$ & Number & > C3* & Price (R) & $(\mathrm{R})$ \\
\hline SAMM & 93 & 0.85 & 20.38 & 16 & 0.37 & 14.53 & 29.3 \\
SAMM Cross & 82 & 0.87 & 20.39 & 15 & 0.53 & 14.27 & 33.1 \\
Dohne & 86 & 0.88 & 20.45 & 14 & 0.36 & 14.56 & 37.0 \\
FW+ Merino & 77 & 0.88 & 20.47 & 15 & 0.07 & 15.04 & 39.5 \\
Rep+ Merino & 80 & 0.87 & 20.39 & 17 & 0.18 & 14.86 & 37.5 \\
\hline
\end{tabular}

* Critical Chi $^{2}$ for 4 degrees of freedom = 9.49; SAMM - South African Mutton Merino;

South African carcass fatness classification on a scale of 1 to 5 , with 1 - very lean, 5 - overfat;

$\mathrm{R}$ - South African Rand;

There was a tendency $(\mathrm{P}<0.10)$ for SAMM cross ewes to have a higher proportion of carcasses that was classified as A4 or fatter when compared to $\mathrm{FW}+$ Merinos $\left(\mathrm{Chi}^{2}=9.33\right.$; degrees of freedom $=4$; $\mathrm{P}<$ 0.10; Table 6). This tendency resulted in fairly large differences in the average price of C-classes between dam lines, with the leaner Merino carcasses achieving slightly higher prices than those of the dual-purpose breeds. Clean wool prices for dam lines increased from R 29.3 for SAMM ewes to R 39.5 for FW+ Merino ewes. Since the average fibre diameter of the ewes in the present study was mostly in the range where the micron premium is low, staple strength was one of the most important contributors to the realised wool prices.

The outcome from the economic simulation suggested gross returns per small stock unit (SSU) of R285 for SAMM ewes, R306 for SAMM cross ewes, R322 for Dohne Merino ewes, R354 for FW+ Merino ewes and R365 for Rep+ Merino ewes when the current (2004) product prices were used. The simulated income derived from the highest yielding Rep+ line was R80 per SSU higher than that obtained from the lowest yielding SAMM ewes. Expressed relatively to SAMM ewes, this difference amounted to $28 \%$ per SSU. When the ratio of the wool price to the meat price is very low $(<1: 1)$, the simulation study suggested that the gross income from dual purpose ewes and FW+ ewes was quite similar (Figure 1). A slightly higher income could be generated from the Rep+ line at this stage. As the ratio of the wool price to the meat price increased, trend-lines for the respective dam lines diverged according to their wool production capacity. This was particularly true in the FW+ Merinos, where a similar income per SSU compared to the Rep+ line was found at the widest wool:meat price ratio included in the simulation. At this stage, the simulated income from the two Merino lines exceeded that of the SAMM line by approximately $37 \%$.

The relative success of the Merino lines seems to stem from two factors, namely their improved wool production capacity relative to the dual-purpose lines and their smaller body size. They were also capable of attaining reproduction rates that were comparable with the larger dual-purpose ewes. A number of references have indicated the contribution of a small maternal size to efficiency in a terminal crossbreeding system (Large, 1970; Dickerson, 1978; Greeff et al., 1990; Schoeman et al., 1995). Dimorphism between the size of male and female breeding animals was pointed out as one factor contributing most to flock cost efficiency (Roux, 1992). Moreover, it was also listed as an adaptation that was easy to achieve. Other factors contributing markedly to the gain in economic efficiency in cattle and sheep were an improved reproduction rate and the improvement of the feed efficiency of female animals. The difficulty in achieving an improved reproduction rate was rated as medium, while an improved feed efficiency of lactating animals was rated as difficult to attain. If it is considered that mature rams of the Dormer and Suffolk breeds are considered to weigh at least $100 \mathrm{~kg}$ (Terblanche, 1979), it is clear that the ratio of ewe weight to sire weight was $\geq 1: 1.76$ in Merinos, compared to 1:1.48 -1:1.54 in ewes from the dual-purpose breeds. 
This study demonstrated substantial differences in the economic output of Merino and Merino-type lines considered. In the study of Fogarty et al. (2001), progeny test results of maternal sires in the lamb industry indicated that there were also marked differences between sires in maternal attributes of first cross ewes. Monetary output generated by progeny of these sires ranged from \$A 158 to \$A 263 over a three year period. When expressed relative to the progeny of the lowest ranking sire, the yield of the best sire was $66 \%$ higher. It thus seems as if ample genetic variation could be exploited within the confines of a structured terminal crossbreeding system.

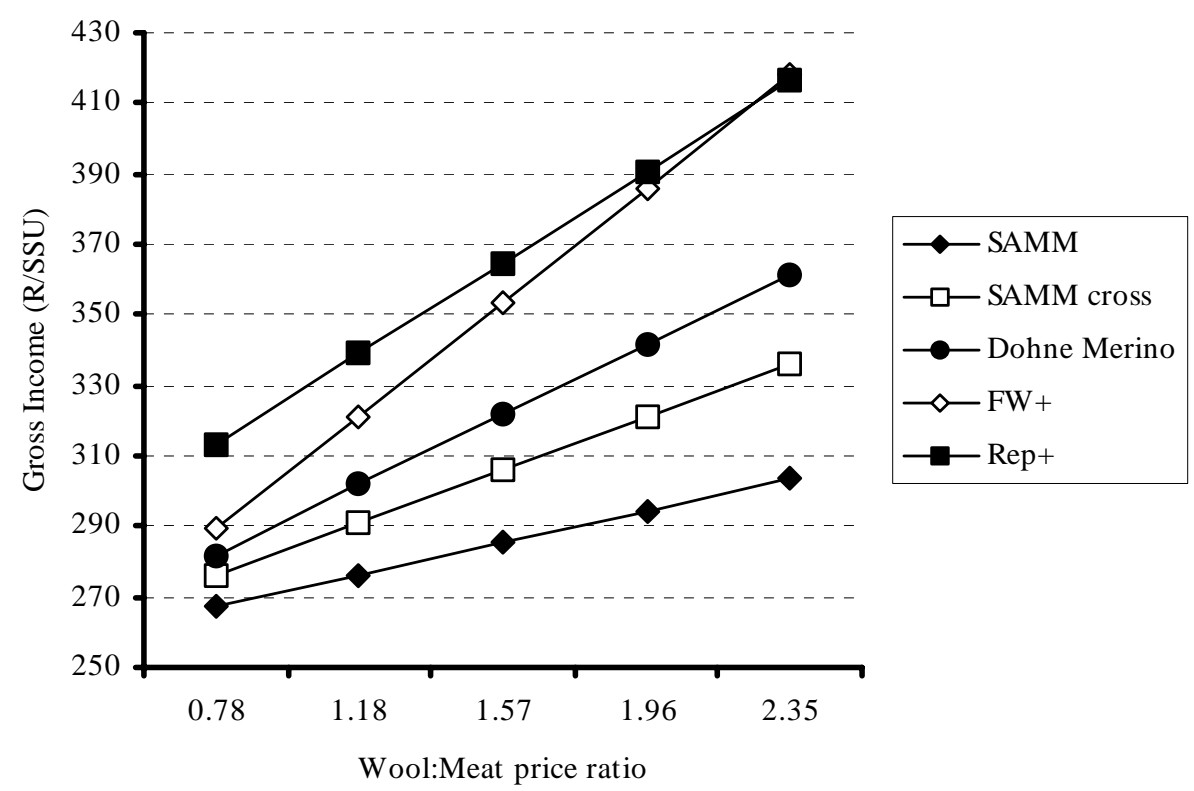

Figure 1 Gross income per small stock unit (SSU) for the respective dam lines when assessed at different wool:meat price ratios

In view of a lack of significant differences in any of the traits involving ewes joined to either Dormer or Suffolk sires, it was not attempted to extend the economic simulation to cover the importance of sire breed. The choice of rams between the two breeds could thus be based on other properties, like the availability and affordability of rams, as well as the higher probability of wool contamination with dark fibres in the case of Suffolk sires. On the other hand, the colour of Suffolk cross lambs in a crossbreeding situation could also be advantageous, to ensure that these lambs are not considered as replacement females in extensive situations where individual records are not kept. Another factor that could be considered is access to national direct breeding values for early growth for all individuals in the terminal sire breed.

\section{Conclusions}

Considerable variation was found between dam lines for live weight, wool yield and reproduction, although few differences in lamb output were significant. The combination of relatively small size with acceptable reproduction and high levels of fibre production resulted in the purebred Merino-types being extremely competitive in terms of economic yield. Further research on the establishment of specialist terminal dam lines is indicated, since it appears to be one of the avenues available for commercial sheep producers to enhance flock efficiency at a limited cost.

\section{Acknowledgement}

We gratefully acknowledge the support of A. Durand and the staff at the Langgewens experimental farm during the experiment, as well as the technical inputs of A.J. Scholtz and J.E. Fourie. The experiment was supported financially by the South African Red Meat Research and Development Trust. The South 
African Wool Industry supported the development of the Rep+ line financially. We are also grateful to the Western Cape Dohne Merino club, for the donation of the 1997 born progeny from the Kromme Rhee nucleus flock. We are also indebted to A. Kotzé, of the South African Suffolk Breeder's Association, who provided Suffolk rams for the experiment.

\section{References}

ARC, 1980. The nutrient requirements of farm livestock. No 2: Ruminants. Agricultural Research Council, Commonwealth Agricultural Bureaux, London.

Basson, W.D., Van Niekerk, B.D.H., Mulder, A.M. \& Cloete, J.G., 1969. The productive and reproductive potential of three breeds mated at 8-monthly intervals under intensive feeding conditions. Proc. S. Afr. Soc. Anim. Prod. 8, 149-154.

Brand, T.S., Franck, F. \& Coetzee, J., 1999. Kikuyu (Pennisetum clandestinum) pasture for sheep. 2. Production and nutritional status of ewes with or without lupin (Lupinus albus) supplementation. N. Z. J. Agric. Res. 42, 467-474.

Bruwer, G.G., Naudé, R.T., Du Toit, M.M., Cloete, A. \& Vosloo, W.A., 1987. An evaluation of the lamb and mutton carcass grading system in the Republic of South Africa. 2. The use of fat measurements as predictors of carcass composition. S. Afr. J. Anim. Sci. 17, 85-89.

Cloete, S.W.P., Cloete, J.J.E., Durand, A. \& Hoffman, L.C., 2003. Production of five Merino-type lines in a terminal crossbreeding system with Dormer or Suffolk sires. S. Afr. J. Anim. Sci. 33, 223-232.

Cloete, S.W.P., Coetzee, J., Schoeman, S.J., Morris, J. \& Ten Hoope, J.M., 1999. Production parameters for Merino, Dohne Merino and South African Mutton Merino sheep. Proc. Assoc. Advmnt Anim. Breed. Genet. 13, 189-193.

Cloete, S.W.P. \& Durand, A., 2000. The crossing of commercial Merino ewes with South African (SA) Meat Merino rams for an increased lamb output. Aust. J. Exp. Agric. 40, 11-16.

Cloete, S.W.P., Olivier, J.J., Snyman, M.A. \& du Toit, E., 1998a. Genetic parameters and trends in a selection experiment for increased clean fleece weight involving South African Merinos. Aust. J. Exp. Agric. 38, 427-432.

Cloete, S.W.P. \& Scholtz, A.J., 1998. Lamb survival in relation to lambing and neonatal behaviour in medium wool Merino lines divergently selected for multiple rearing ability. Aust. J. Exp. Agric. 38, 801-811.

Cloete, S.W.P., Scholtz, A.J. \& Aucamp, B.B., 1998b. Environmental effects, heritability estimates and genetic trends in a Western Cape Dohne Merino nucleus flock. S. Afr. J. Anim. Sci. 28, 185-195.

Dickerson, G.E., 1978. Animal size and efficiency: basic concepts. Anim. Prod. 27, 367-379.

Erasmus, L.S., 1965. Slaglamproduksie met die Merino as moederooi. M.Sc. (Agric.)-verhandeling, Universiteit van Stellenbosch, Suid-Afrika.

Erasmus, L.S., De Kock, J.A. \& Grobler, J.W., 1983. Slaglamproduksie in die Suid-Kaap. Elsenburg J. 7, 13-32.

Fogarty, N.M., Cummings, L., Gaunt, G., Hocking-Edwards, J., Edwards, N., Lees, K. \& Morgan, J., 2001. Opportunities to exploit genetic variation among maternal sires in the lamb industry. Proc. Assoc. Advmt Anim. Breed. Gen. 14, 123-126.

Fourie, A.J., 1981. 'n Studie van fenotipiese en genetiese aspekte van produksie-eienskappe van die DohneMerinokudde op die Dohne navorsingsinstituut. M.Sc. (Agric.)-verhandeling, Universiteit van Stellenbosch, Stellenbosch, Suid-Afrika.

Fourie, A.J. \& Cloete, S.W.P., 1993. Reproductive performance of commercial Merino, Dohne Merino and SA Mutton Merino flocks in the Southern Cape. S. Afr. J. Anim. Sci. 23, 104-110.

Greeff, J.C., 1990. The Merino and modern production systems. Proc. World. Merino Conf. Volume 1, 3.2, 1-33. 2-4 May, 1990, Pretoria, South Africa. (Merino Studbreeders' Society of South Africa, P.O. Box 109, Graaff-Reinet 6280, South Africa.)

Greeff, J.C., Roux, C.Z. \& Wyma, G.A., 1990. Lifetime meat production from six different F1 crossbred ewes. S. Afr. J. Anim. Sci. 20, 71-77.

Harvey, W.R. 1990. User's guide for LSMLMW and MIXMDL. PC-2 version, Mimeograph. Columbus, Ohio, USA.

Herselman, M.J., 2002. The role of simulation models in agricultural extension. Proc. $1^{\text {st }}$ Joint Cong. Grassl. Soc. Sthn Afr. \& S. Afr. Soc. Anim. Sci., 13 - 16 May 2002, Cristiana Aventura, pp 46a-46c. 
Heydenrych, H.J., 1975. 'n Studie van kuddestatistieke, nie-genetiese faktore genetiese parameters, en seleksievordering met betrekking tot die Tygerhoek Merinokudde. Ph.D. proefskrif, Universiteit van Stellenbosch, Stellenbosch, Suid-Afrika.

Kirton, A.H., Carter, A.H., Clarke, J.N., Sinclair, D.P., Mercer, G.J.K. \& Duganzich, D.M., 1995. A comparison between 15 ram breeds for export lamb production 1. Liveweights, body composition, carcass measurements and composition. N. Z. J. Agric. Res. 38, 347-360.

Kleeman, D.O., South, M.H.L., Dolling, C.H.S. \& Ponzoni, R.W., 1983. Survival, growth and wool production of South Australian strong-wool Merino and first-cross Merino lambs from birth to 16 months of age. Aust. J. Exp. Agric. Anim. Husb. 23, 271-279.

Knight, T.W., 1990. Reproductive wastage, a guide for fundamental research: a New Zealand perspective. In: Reproductive physiology of Merino sheep - concepts and consequences. Eds. Oldham, C.M., Martin, G.B. \& Purvis, I.W., School of Agriculture (Animal Science), The University of Western Australia, Nedlands 6009, WA, Australia. pp. 11-21.

Large, R.V., 1970. The biological efficiency of meat production in sheep. Anim. Prod. 12, 393-401.

Malik, R.C., AI-Khozam, N.M. \& Abbas, S.A., 2000. Crossbreeding for intensive lamb production: reproduction, lamb survival and growth. Proc. Aust. Soc. Anim. Prod. 32, 173-176.

Rathie, K.A. \& Teasdale, C.K., 1994. Assessing Wiltshire Horn-Merino crosses. 3. The 50\% Wiltshire Horn as a prime lamb producer. Aust. J. Exp. Agric. 34, 733- 739.

Roux, C.Z., 1992. Maximum herd efficiency in meat production. III. Feeder-breeder dimorphism. S. Afr. J. Anim. Sci. 22, 11-15.

Schoeman, S.J., De Wet, R., Botha, M.A. \& Van der Merwe, C.A., 1995. Comparative assessment of biological efficiency of crossbred lambs from two composite lines and Dorper sheep. Small Rumin. Res. 16, 61-67.

Siegel, S., 1956. Non parametric statistics for the behavioral sciences. McGraw-Hill Inc., New York.

Terblanché, E. le F., 1979. Ken ons kleinveerasse. Human en Rousseau Uitgewers, Kaapstad, Suid-Afrika.

Van Wyk, J.B., Fair, M.D. \& Cloete, S.W.P., 2003. Revised models and genetic parameters for production and reproduction traits in the Elsenburg Dormer stud. S. Afr. J. Anim. Sci. 33, 213-222.

Vosloo, L.P., 1967. Faktore wat die produksie en reproduksie van die Elsenburg Duitse Merinokudde beïnvloed. D.Sc. proefskrif, Universiteit van Stellenbosch, Stellenbosch, Suid-Afrika.

White, D.H., 1984. Economic values of changing reproductive rate. In: Reproduction in Sheep. Eds. Lindsay, D.R. \& Pearce, D.T., Australian Academy of Science in Conjunction with Australian Wool Corporation, Canberra, Australia. pp. 371 - 377. 